\title{
Penyuluhan tentang Aktifitas Fisik dalam Peningkatan Status Kesehatan
}

\author{
Udin Rosidin, Nina Sumarni, Iwan Suhendar \\ Fakultas Keperawatan, Universitas Padjadjaran \\ Email: dinr8629@gmail.com
}

\begin{abstract}
Abstrak
Melakukan aktifitas fisik merupakan salah satu indikator dalam pelaksanaan PHBS. Dalam survey awal yang dilakukan penulis menunjukkan bahwa di Desa Jayaraga sebesar 36,8 tidak melakukan aktifitas fisik. Padahal apabila dilihat dari letak geografisnya sangat dekat dengan sarana olah raga. Indikator lain ditemukan sebesar 3,8\% pertolongan persalinan tidak oleh nakes, 5,8\% balita tidak ditimbang di posyandu. Rendahnya aktifitas fisik akan berdampak pada meningkatnya prevalensi penyakit degeneratif yang akibatnya pada penurunan status kesehatan. Melakukan aktifitas fisik adalah cara untuk meningkatkan status kesehatan. Hambatan yang menyebabkan rendahnya pelaksanaan aktifitas fisik diantaranya adalah pengetahuan, motivasi dan ketersediaan sarana. Upaya yang dapat dilaksanakan untuk meningkatkan pengetahuan adalah penyuluhan. Tujuan kegiatan ini adalah untuk meningkatkan pengetahuan masyarakat tentang pentingnya aktifitas fisik bagi kesehatan. Metoda pelaksanaannya adalah melakukan penyuluhan. Melalui program ini masyarakat diberi pemahaman tentang pentingnya melaksanakan aktiifitas fisik bagi kesehatan. Jumlah peserta penyuluhan sebanyak 41 orang. Kegiatan dimulai dari tahapan perencanaan, pelaksanaan, evaluasi, hingga penyusunan laporan. Hasil kegiatan menunjukan bahwa rata rata nilai pengetahuan masyarakat sebelum dilaksanakan penyuluhan dari range 0 sampai dengan 100 sebesar 61,6. Sedangkan setelah dilaksanakan penyuluhan sebesar 69. Dari hasil tersebut dibuktikan bahwa ada peningkatan pengetahuan masyarakat tentang pentingnya aktifitas fisik setelah dilakukan penyuluhan. Kesimpulan. Pelaksanaan kegiatan ini dapat meningkatkan pengetahuan masyarakat tentang pentingnya aktifitas fisik bagi kesehatan. Rencana tidak lajut dari kegiatan ini adalah melaksanakan kerjasama dengan petugas kesehatan untuk melakukan pembinaan dan bimbingan kepada masyarakat tentang hidup sehat.
\end{abstract}

Kata kunci : Aktifitas fisik, penyuluhan, PHBS.

\begin{abstract}
Performing physical activity is one indicator in the implementation of Clean and Healthy Behavior. In the initial survey the author showed that $36.8 \%$ in Jayaraga Village did not carry out physical activities. Even though when viewed from its geographical location it is very close to sports facilities. Another indicator was found that is $3.8 \%$ of childbirth assistance was not performed by health workers, $5.8 \%$ of children under five were not weighed at the compound service post. Low physical activity will have an impact on the increasing prevalence of degenerative diseases which results in a decrease in health status. Performing physical activity is a way to improve health status. Hindrance that cause the low implementation of physical activities include knowledge, motivation and availability of facilities. Efforts that can be implemented to increase knowledge are health education. The purpose of this activity is to increase community knowledge about the importance of physical activity for health. The method of implementation is counseling. Through this program the community is given an understanding of the importance of carrying out physical activities for health. The number of that was 41 participants. The activity starts from the stages of planning, implementation, evaluation, until the preparation of the report. The results of the activities showed that the average value of community knowledge before the counseling was carried out from a range of 0 to 100 amounted to 61.6. Whereas after counseling was carried out by 69. From these results it was proven that there was an increase in community knowledge about the importance of physical activity after counseling. Conclusion. The implementation of this activity can increase community knowledge about the importance of physical activity for health. The follow up plan of this activity is carrying out collaboration with health workers to provide guidance and guidance to the community about healthy living.
\end{abstract}

Keywords: Physical Activity, Counseling, Clean and Healthy Behavior. 
Udin Rosidin : Penyuluhan tentang Aktifitas Fisik dalam Peningkatan Status Kesehatan

\section{Pendahuluan}

Masalah kesehatan masyarakat saat ini sangat kompleks dan sangat beragam. Masalah tersebut muncul ditentukan oleh kebiasaan masyarakat mengenai perilaku hidup bersih dan sehat. Perilaku Hidup Bersih dan Sehat harus diterapkan dalam setiap sisi kehidupan manusia seperti di rumah tangga/keluarga, institusi kesehatan, tempat-tempat umum, sekolah maupun di tempat kerja. Dasar hukum pelaksanaan Perilaku Hidup Bersih dan Sehat adalah Peraturan Menteri Kesehatan Republik Indonesia nomor 2269/MENKES/PER/XI/2011 yang mengatur upaya peningkatan perilaku hidup bersih dan sehat di seluruh Indonesia. Perilaku Hidup Bersih dan Sehat adalah seperangkat perilaku yang dipraktikkan atas dasar kesadaran sebagai hasil dari pembelajaran, yang membuat seseorang atau keluarga dapat membantu dirinya sendiri dalam kesehatan dan memainkan peran aktif dalam mewujudkan kesehatan masyarakat. Perilaku Hidup Bersih dan Sehat merupakan salah satu indikator untuk menilai kinerja pemerintah daerah kabupaten / kota di bidang kesehatan (Kemenkes, 2013).

Pencapaian rumah tangga sehat di Kabupaten Garut pada tahun 2014 sebesar 51,70 \% (Dinas Kesehatan Kabupaten Garut, 2015). Angka tersebut lebih rendah dari angka nasional $(56,58 \%)$. Data hasil survey awal yang dilakukan penulis menunjukkan bahwa indikator PHBS tentang kebiasaan masyarakat di Desa Jayaraga sebesar 36,8\% tidak melakukan aktivitas fisik. Padahal apabila dilihat dari letak geografisnya Desa Jayaraga sangat dekat dengan pusat kegiatan sarana olah raga. Rendahnya aktifitas fisik tersebut akan berdampak pada meningkatnya prevalensi penyakit degeneratif. Menurut Sarvasti (2012) bahwa pada saat ini terjadi pergeseran pola penyakit dari penyakit infeksi dan malnutrisi degeneratif.

Secara umum hasil studi diberbagai negara menyebutkan bahawa aktfitas fisik yang memadai bermanfaat untuk kesehatan terutama mengurangi resiko penyakit-penyakit kronis seperti penyakit jantung, stroke, diabetes mellitus tipe 2, obesitas dan gizi lebih, penyakit kanker payudara, kanker kolon serta depresi. Hasil penelitian menunjukkan bahwa aktifitas fisik memberikan keuntungan yang besar untuk menurunkan resiko penyakit jantung. Orang yang kurang melakukan aktifitas fisik beresiko dua kali lebih besar terkena penyakit jantung bila dibandingkan orang yang tidak aktif. Aktifitas fisik juga membantu mencegah penyakit stroke dan memperbaiki faktor resiko cardiovascular disease (CVD) seperti tekanan darah tinggi dan tinggi kolesterol (Welis, 2013). 
Udin Rosidin : Penyuluhan tentang Aktifitas Fisik dalam Peningkatan Status Kesehatan

Menurut Lestari (2010) menyatakan adanya hubungan antara aktifitas fisik dengan kejadian hipertensi $(\mathrm{p}=0,042)$. Hasil penelitian ini membuktikan bahwa peningkatan aktifitas fisik menurunkan risiko terjadinya hipertensi. Aktifitas fisik yang dilakukan secara rutin juga memperbaiki psikologis seseorang melalui penurunan stress, kecemasan dan depresi. Faktor psikologis penting dipertimbangkan untuk pencegahan dan manajemen penyakit jantung serta berimplikasi juga terhadap penyakit kronis lainnya seperti diabetes, osteoporosis, hipertensi, kegemukan kanker dan depresi (Welis, 2013).

Secara umum menurut Welis (2013) dalam bukunya Gizi untuk Aktifitas Fisik dan Kebugaran menjelaskan bahwa manfaat aktifitas fisk untuk kesehatan ada dua yaitu manfaat fisik/biologis dan manfaat psikologis. Manfaat fisik/biologis meliputi : menjaga tekanan darah tetap stabil dalam batas normal, meningkatkan daya tahan tubuh terhadap penyakit, menjaga berat badan ideal, menguatkan tulang dan otot, meningkatkan kelenturan tubuh, dan meningkatkan kebugaran tubuh. Sedangkan manfaat aktifitas fisik secara psikis/mental dapat : mengurangi stress, meningkatkan rasa percaya diri, membangun rasa sportifitas, memupuk tanggung jawab, dan membangun kesetiakawanan sosial.

Melihat pentingnya aktifitas fisik untuk kesehatan tersebut sangatlah perlu dilakukan oleh semua masyarakat. Masalah rendahnya kegiatan aktifitas fisik apabila terus dibiarkan, akan menjadi masalah yang harus segera ditanggulangi. Kehidupan dan keadaan masa depan sangat bergantung dengan kondisi saat ini, oleh karena itu perlu adanya langkah yang nyata untuk menangani masalah kesehatan tersebut. Namun dalam penerapannya, kendala di masyarakat kerap kali menjadi penghambat. Salah satu hambatan diantaranya kurangnya pengetahuan dan kesadaran akan pentingnya aktifitas fisik.

Pengetahuan tentang pentingnya aktifitas fisik bagi kesehatan adalah faktor yang sangat menentukan seseorang melakukan aktifitas fisik atau tidak. Menurut Green yang diambil dari Notoatmodjo (2010) menegaskan bahwa perilaku kesehatan dapat dilaksanakan dengan baik apabila didukung oleh tiga faktor, yaitu 1). Predisposing factors seperti pengetahuan, sikap, kepercayaan, keyakinan dan nilai nilai, 2), Enabling factors yang terwujud dalam lingkungan fisik dan sarana (fasilitas) kesehatan dan 3). Reinforcing factors yang terwujud dalam sikap dan perilaku petugas kesehatan. Pendapat lain dikemukaan oleh Welis (2013) bahwa faktor individu seperti pengetahuan dan persepsi tentang hidup sehat, motivasi, kesukaan berolahraga, harapan tentang keuntungan 
melakukan aktifitas fisik akan mempengaruhi seseorang melakukan aktifitas fisik. Dari teori tersebut dibuat kerangka pemikiran bahwa karena aktiftas fisik merupakan sebuah perilaku maka dalam pelaksanaan diperlukan pengetahuan yang cukup. Orang yang memiliki pengetahuan dan persepsi yang baik terhadap hidup sehat akan melakukan aktifitas fisik dengan baik, karena mereka yakin dampak aktifitas fisik tersebut terhadap kesehatan. Apalagi orang yang mempunyai motivasi dan harapan untuk mencapai kesehatan optimal, akan terus melakukan aktifitas fisik sesuai anjuran kesehatan.

Berdasarkan pembahasan tersebut diatas, aktifitas fisik merupakan hal yang sangat penting untuk meningkatkan status kesehatan. Tapi kenyatannya dalam survey awal menunjukkan bahwa masyarakat yang melaksanakan aktifitas fisik masih rendah, padahal faktor sarana dan fasilitas untuk melakukan aktifitas fisik sangat mendukung. Hal itu terjadi dimungkinkan ada faktor lain seperti pengetahuan yang menyebabkan masyarakat tidak melakukan aktifitas fisik. Manfaat dari kegiatan ini adalah meningkatkan pengetahuan masyarakat, sehingga aktifitas fisik merupakan kebutuhan sehari hari. Memperhatikan hal tersebut penulis tertarik untuk melakukan kegiatan pengabdian pada masyarakat dengan memberikan penyuluhan tentang pentingnya aktifitas fisik bagi kesehatan.

\section{Metode}

Pelaksanaan Program Pengabdian Masyarakat ini adalah penyuluhan tentang pentingnya aktifitas fisik bagi kesehatan di Desa Jayaraga Kabupaten Garut. Aktifitas fisik adalah gerakan tubuh yang dihasilkan oleh otot rangka yang mengakibatkan pengeluaran energi dan berhubungan positif dengan kebugaran (Welis, 2013). Sasaran kegiatan adalah seluruh warga RW 12 Desa Jayaraga. Kegiatan ini menekankan pada partisipasi peserta penyuluhan untuk mengikuti semua kegiatan mulai dari pre test, ceramah serta diskusi dan post test. Sebelum kegiatan pengabdian dilakukan terlebih dahulu melakukan survey awal untuk mengetahui permasalahan yang ada terkait pelaksanaan PHBS. Jumlah peserta penyuluhan yang hadir dalam pelaksanaan kegiatan tersebut adalah sebanyak 41 orang. Tujuan kegiatan adalah untuk memberikan pemahaman kepada masyarakat tentang pentingnya aktifitas fisik bagi kesehatan.

Metode yang digunakan dalam kegiatan pengabdian ini diawali dengan kajian literatur. Dalam tahap ini penulis mencari artikel yang sesuai dengan thema penyuluhan sebagai rujukan untuk mencari materi yang tepat. Kemudian tahap persiapan dengan 
melakukan pendekatan sosial kepada Kepala Puskesmas, Kepala Desa, RW dan kader kasehatan. Pada tahap perencanaan ini penuls berkoordinasi dengan kader kesehatan dan aparat pemerintah desa untuk menyepakati kembali tujuan, waktu, tempat dan peserta kegiatan. Kemudian tahap pelaksanaan penyuluhan. Dalam tahap pelaksanaan ini kegiatan terdiri dari beberapa sesi, pertama yaitu pre test kemudian pemberian materi dan diskusi kemudian diakhiri dengan post test. Metode ceramah dalam penyuluhan dimaksudkan untuk memberikan pemahaman tentang pentingnya aktifitas fisik bagi kesehatan. Kemudian dilakukan diskusi dengan harapan masyarakat akan lebih merasakan dan menjadi kebutuhan sehari hari untuk melaksanakan aktifitas fisik. Tahap akhir yaitu melakukan evaluasi untuk mengetahui apakah kegiatan pengabdian ini mencapai tujuan atau tidak. Evaluasi dilakukan dengan cara membandingkan rata rata nilai pengetahuan peserta sebelum dan sesudah dilaksanakan penyuluhan. Analisis yang digunakan adalah analisis univariat dan bivariat. Analisis univariat dimaksudkan untuk untuk mengetahui penyebaran katagori tingkat pengetahuan serta perbedaan rata rata nilai pengetahuan sebelum dan sesudah dilaksanakan penyuluhan. Sedangkan analisis bivariat untuk mengetahui peranan karakteristik dalam meningkatkan pengetahuan masyarakat. Hasil kegiatan disajikan dalam bentuk distribusi frekuensi.

\section{Hasil}

Kegiatan pengabdian ini diikuti dengan antusias oleh seluruh peserta dan mendapat apresiasi positif dari ketua RW dan pemerintahan desa maupun dari pihak puskesmas yang saat pelaksanaan kegiatan penyuluhan ikut hadir. Karakteristik peserta penyuluhan terdiri jenis kelamin, umur, pendidikan dan pekerjaan. Data selengkapnya adalag sebagai berikut

\section{Tabel 1 Karakteristik Peserta Penyuluhan}

\begin{tabular}{clcc}
\hline \multirow{2}{*}{ No } & \multicolumn{1}{c}{ Karakteristik } & Frekuensi & $\begin{array}{c}\text { Persentase } \\
\%\end{array}$ \\
\hline 1 & Jenis Kelamin & & \\
& Laki laki & 10 & 24,4 \\
& Perempuan & 31 & 75,6 \\
\hline 2 & Umur & & \\
& 26-45 Tahun & 12 & 29,3 \\
& $46-65$ Tahun & 24 & 58,5 \\
& Diatas 65 Tahun & 5 & 12,2 \\
\hline 3 & Pendidikan & & 56.1
\end{tabular}




\begin{tabular}{llcc} 
& Tinggi & 18 & 44,9 \\
\hline 4 & Pekerjaan & & \\
& Bekerja & 10 & 24,4 \\
& Tidak bekerja & 31 & 75,6 \\
\hline
\end{tabular}

Dari tabel 1 diatas dapat dilihat bahwa peserta penyuluhan sebagian besar perempuan yaitu sebanyak $75,6 \%$. Kelompok umur berada pada usia 46 - 65 tahun yaitu sebanyak 58,8\%. Pendidikan peserta penyuluhan yang paling banyak adalah pendidikan rendah yaitu 56,1 \% dan karakteristik pekerjaan sebanyak 75,6 \% tidak bekerja.

Kegiatan penyuluhan diawali dengan pengukuran pengetahuan sebelum dan diakhiri dengan pengukuran pengetahuan setelah dilakukan penyuluhan. Hasil pre test dapat dilihat pada tabel 2 berikut ini :

Tabel 2. Distribusi Frekuensi Peserta Penyuluhan berdasarkan Pengetahuan Sebelum dilakukan Penyuluhan

\begin{tabular}{ccccc}
\hline No & Katagori Pengetahuan & Frekuensi & $\begin{array}{c}\text { Persentase } \\
\%\end{array}$ & $\begin{array}{c}\text { Rata rata } \\
\text { nilai }\end{array}$ \\
\hline 1 & Kurang (nilai 0-56) & 7 & 17 & 61,66 \\
2 & Cukup (nilai 57-75) & 25 & 61 & \\
3 & Baik (nilai 76-100) & 9 & 22 & \\
\hline \multicolumn{1}{c}{ Jumlah } & 41 & 100 & \\
\hline
\end{tabular}

Dari tabel diatas, pengetahuan dikelompokan menjadi 3 kategori yaitu baik, cukup dan kurang. Rentang kategori baik adalah skor 76-100. Kategori cukup adalah skor yang dimulai dari 57-75 dan kategori kurang adalah untuk peserta yang mendapat skor 0-56.

Dari 41 peserta penyuluhan didapatkan data sebanyak $17 \%$ peserta berada dalam kategori kurang, $61 \%$ peserta berada dalam kategori cukup dan $22 \%$ peserta berada dalam kategori baik. Rata rata nilai sebelum dilakukan penyuluhan adalah sebesar 61,66. Seteleh dilakukan penyuluhan maka distribusinya dapat dilihat pada tabel 3 berikut :

Tabel 3. Distribusi Frekuensi Peserta Penyuluhan berdasarkan Pengetahuan Setelah dilakukan Penyuluhan

\begin{tabular}{|c|c|c|c|c|}
\hline No & Katagori Pengetahuan & Frekuensi & $\begin{array}{c}\text { Persentase } \\
\%\end{array}$ & $\begin{array}{c}\text { Rata rata } \\
\text { nilai }\end{array}$ \\
\hline 1 & Kurang (nilai 0-56) & 2 & 5 & 69,0 \\
\hline 2 & Cukup (nilai 57-75) & 29 & 71 & \\
\hline 3 & Baik (nilai 76-100) & 10 & 24 & \\
\hline & Jumlah & 41 & 100 & \\
\hline
\end{tabular}


Dari tabel 3 diatas hasil posttest di atas, kita dapat lihat bahwa dari 41 peserta sebanyak $5 \%$ peserta berada dalam kategori kurang, $71 \%$ peserta berada dalam kategori cukup dan $24 \%$ peserta berada dalam kategori baik. Rata rata nilai pengetahuan setelah dilakukan penyuluhan sebesar 69,0. Data tingkat pengetahuan setelah dilakukan penyuluhan tersebut apabila di dilihat dari karakteristiknya maka terlihat pada tabel 4 berikut ini.

Tabel 4 Hubungan Karakteristik dengan Tingkat Pengetahuan Responden setelah dilakukan Penyuluhan

\begin{tabular}{|c|c|c|c|c|c|c|}
\hline \multirow{3}{*}{ No } & \multirow{3}{*}{ Karakteristik } & \multicolumn{4}{|c|}{ Pengetahuan } & \multirow{3}{*}{$\begin{array}{c}\text { P Value / } \\
\text { OR }\end{array}$} \\
\hline & & \multicolumn{2}{|c|}{ Kurang } & \multicolumn{2}{|c|}{ Baik } & \\
\hline & & $\mathrm{F}$ & $\%$ & $\mathrm{~F}$ & $\%$ & \\
\hline \multirow[t]{3}{*}{1} & Jenis Kelamin & & & & & $0,65 / 1,3$ \\
\hline & Laki-Laki & 5 & 50 & 5 & 50 & \\
\hline & Perempuan & 13 & 41,9 & 18 & 58,1 & \\
\hline \multirow[t]{4}{*}{2} & Umur & & & & & 0,95 \\
\hline & 26 - 45 Tahun & 5 & 41,7 & 7 & 58,3 & \\
\hline & 46 - 65 Tahun & 11 & 45,8 & 13 & 54,2 & \\
\hline & Diatas 65 Tahun & 2 & 40 & 3 & 60 & \\
\hline \multirow[t]{3}{*}{3} & Pekerjaan & & & & & $0,72 / 0,7$ \\
\hline & Bekerja & 5 & 50 & 5 & 50 & \\
\hline & Tidak Bekerja & 13 & 41,9 & 18 & 58,1 & \\
\hline \multirow[t]{3}{*}{4} & Pendidikan & & & & & $0,70 / 0,6$ \\
\hline & Rendah & 9 & 39,1 & 14 & 60,9 & \\
\hline & Tinggi & 9 & 50 & 9 & 50 & \\
\hline
\end{tabular}

Dari tabel 4 diatas dapat dilihat bahwa peserta penyuluhan yang berjenis kelamin laki laki sebanyak $50 \%$ memiliki pengetahuan baik dan kurang. Sedangkan jenis kelamin perenpuan sebanyak $58,1 \%$ memiliki pengetahuan baik dengan nilai $\mathrm{P}$ sebesar 0,65. Pada karakteristik umur, kelompok umur 26-45 sebanyak 58,3 memiliki pengetahuan baik, kelompok umur 46-65 sebanyak 54,2 \% pengetahuan baik dan kelompok umur diatas 65 tahun juga sebagian besar neniliki pengetahuan baik yaitu sebanyak $60 \%$ dengan nilai p sebesar 0,95. Pada karakteristik pekerjaan, peserta yang bekerja sebanyak $50 \%$ memiliki pengetahuan baik dan kurang, sedangkan pada peserta yang tidak bekerja sebanyak 58,1\% memiliki pengetahuan baik dengan nilai $\mathrm{p}$ sebesar 0,72. Pada karakteristik pendidikan, kelompok pendidikan rendah sebanyak $60,9 \%$ memiliki pengetahuan baik dan pafa kelompok pendidikan tinggi sebanyak $50 \%$ memiliki pengetahuan baik dan kurang dengan nilai $\mathrm{p}$ sebesar 0,70 . 


\section{Pembahasan}

Kegiatan pengabdian pada masyarakat dengan bentuk penyuluhan tentang pentingnya aktifitas fisik bagi kesehatan menunjukkan adanya peningkatan pengetahuan peserta penyuluhan. Rata rata nilai pengetahuan peserta kegiatan sebelum dilakukan penyuluhan adalah sebesar 61,6 point, sedangkan setelah dilakukan penyuluhan meningkat menjadi 69 point. Peningkatan rata rata nilai tersebut sangat mungkin karena kegiatan penyuluhan yang dilaksanakan sangat disesuaikan dengan kebutuhan peserta penyuluhan. Materi penyuluhan dikemas sehingga menjadi bahan informasi yang sangat mudah untuk dipahami.

Adanya informasi tentang pentingnya aktifitas fisik bagi kesehatan menjadikan peserta penyuluhan lebih memahami tentang materi yang diberikan. Hasil ini sejalan dengan Kosasih (2018) bahwa terjadi peningkatan tingkat pengetahuan kader kesehatan sebelum dilakukan pelatihan dan sesudah dilakukan pelatihan. Pelatihan yang dilakukan berhubungan dengan penyampaian informasi, dengan demikian maka penyuluhan ini juga mempengaruhi pengetahuan sesorang dengan menyampaikan informasi tertentu. Penyuluhan kesehatan sebagai bagian dari promosi kesehatan bertujuan untuk memiliki dampak positif bagi peserta penyuluhan. Menurut Mardhyah (2019) promosi kesehatan memberikan manfaat pada peserta. Dalam kegiatan pengabdiannya yang berjudul : Promosi Kesehatan Kepada Orang Tua Mengenai Perilaku Hidup Bersih dan Sehat untuk Mencegah Hepatitis A pada Anak. Menyebutkan dengan mengetahui penyebab hepatitis bagi klien maka apabila ada anggota keluarga menderita penyakit yang sama, anggota keluarga dan klien siap menghadapi resiko terburuk dari penyakit hepatitis beserta komplikasinya. Hasil dari informasi pada tahap promosi kesehatan diharapkan klien melakukan kegiatan sesuai dengan pengetahuannya.

Peningkatan pengetahuan peserta penyuluhan dalam kegiatan ini hanya 7,4 point setelah dilakukan penyuluhan. Hal tersebut sangat dimungkinkan karena secara statistik didapatkan nilai $\mathrm{p}$ value diatas 0,05 untuk semua karakteristik dengan nilai resiko yang sangat rendah. Hal tersebut menunjukkan bahwa tidak ada hubungan antara karakteristik dengan peningkatan pengetahuan. Dari uji statistik tersebut karakteristik peserta penyuluhan tidak terbukti memberikan kontribusi dalam peningkatan pengetahuan. Hal ini tidak sejalan dengan teori yang dikemukakan oleh Notoatmodjo (2010) bahwa karakteristik sosial budaya, pengalaman dapat mempengaruhi pengetahuan, keinginan, sikap dan niat seseorang dalam melaksanakan sebuah perilaku. Penelitian lain yang dilakukan oleh 
Udin Rosidin : Penyuluhan tentang Aktifitas Fisik dalam Peningkatan Status Kesehatan

Oktarina dkk (2009) tentang hubungan antara karakteristik responden, keadaan wilayah dengan pengetahuan, sikap terhadap HIV/AIDS pada masyarakat Indonesia menunjukkan bahwa ada hubungan antara karakteristik responden yaitu jenis kelamin, pendidikan dan pekerjaan dengan pengetahuan seseorang. Tidak ada hubungan antara karakteristik dengan peningkatan pengetahuan masyarakat dalam kegiatan ini dikarenakan peserta penyuluhan secara geografis berada di lingkungan kota. Sehingga informasi yang didapat oleh masyarakat akan dipahami sama oleh semua kelompok umur, laki laki atau perempuan, bekerja atau tidak bekerja dan pendidikatn rendah ataupun pendidikan tinggi.

Meningkatnya pengetahuan peserta penyuluhan tentang pentingnya aktifitas fisik bagi kesehatan merupakan faktor predisposisi yang baik untuk melaksanakan Perilaku Hidup Bersih dan Sehat (PHBS). Selain pengetahuan tentunya harus diperhatikan faktor lain seperti persepsi, motivasi fasilitas dan faktor lainnya. Sehingga melakukan aktifitas fisik merupakan kebutuhan bagi setiap orang yang pada akhirnya dapat melaksanakan PHBS. Untuk mencapai kondisi tersebut sangat diperlukan adanya bimbingan dan pembinaan secara rutin oleh petugas kesehatan sehingga masyarakat tahu, mau dan mampu melaksanakan PHBS.

Menurut Lestari (2010) bahwa aktifitas fisik yang dilakukan oleh sebagian besar masyarakat merupakan kegiatan rutin ibu rumah tangga. Aktifitas fisik lain berupa olahraga jarang dilakukan karena kesibukan dalam melakukan kegiatan rutin di rumah. Memperhatikan hal tersebut sangat diperlukan pengetahuan yang cukup dari setiap orang agar melakukan aktifitas fisik secara benar yaitu dengan cara melakukan olah raga setiap hari minimal 30 menit (Kemenkes, 2013). Olah raga yang teratur seperti aerobik, lari, renang, dan bersepeda dapat meningkatkan aktifitas fisik. Hasil penelitian Lestari (2010) membuktikan bahwa peningkatan aktifitas fisik dapat menurunkan risiko terjadinya hipertensi. Besarnya penurunan resistensi tergantung pada beban atau aktivitas fisik yang dilakukan.

\section{Simpulan}

Berdasarkan hasil evaluasi kegiatan penyuluhan tentang pentingnya aktifitas fisik bagi kesehatan menunjukkan adanya peningkatan rata rata nilai pengetahuan sebelum dan sesudah dilaksanakan penyuluhan. Pengetahuan masyarakat tersebut merupakan awal untuk meningkatkan motivasi masyarakat sehingga melakukan aktifitas fisik. Sehingga diharapkan melakukan aktifitas fisik merupakan kebutuhan. Rencana tindak lanjut dari 
kegiatan pengabdian ini adalah kerjasama dengan instansi terkait agar pelaksanakan PHBS dapat dilaksanakan oleh masyarakat. Bentuk kerjasama berupa kegiatan yang rutin seperti pembinaan dan bimbingan secara bersama antara institusi pendidikan kesehatan dengan petugas kesehatan yang ada di Puskesmas.

\section{Ucapan Terimakasih}

Penulis menyampaikan terimakasih kepada semua pihak yang telah membantu dalam pelaksanaan kegiatan Program Pengabdian Masyarakat ini. Secara khusus penulis ingin mengucapkan terimakasih dan penghargaan yang setinggi-tingginya kepada: Rektor Universitas Padjadjaran dan Dekan fakultas Keperawatan Universitas Padjadjaran atas kesempatan dan dukungan yang telah diberikan kepada penulis untuk dapat melaksanakan kegiatan Program Pengabdian Masyarakat ini. Penulis juga menyampaikan terimakasih kepada Kepala desa Jayaraga Kabupaten Garut, Puskesmas Haurpanggung Kabupaten Garut, serta para kader kesehatan Desa Jayaraga, atas kesempatan dan partisipasinya dalam pelaksanaan kegiatan Program Pengabdian Masyarakat ini. Semoga Alloh SWT membalasnya. Aamiin.

\section{Daftar Pustaka}

Dinas Kesehatan Kabupaten Garut. (2015). Pembangunan Kesehatan Kabupaten Garut tahun 2010- 2015.

Kementerian Kesehatan. (2013). PHBS Di Rumah Tangga.

Kosasih, C. E., Isabella, C., \& Sriati, A. (2018). Upaya Peningkatan Gizi Balita Melalui Pelatihan Kader Kesehatan di Desa Cilumba dan Gunungsari Kabupaten Tasikmalaya. Media Karya Kesehatan, 1(1).

Lestari, Dian, 2010, Hubungan Asupan Kalium, Kalsium, Magnesium, Dan Natrium, Indeks Massa Tubuh, Serta Aktifitas Fisik Dengan Kejadian Hipertensi Pada Wanita Usia 30 - 40 Tahun, Program Studi Ilmu Gizi Fakultas Kedokteran, Universitas Diponegoro, Semarang.

Mardhiyah, A., Mediani, H. S., \& Rahayuwati, L. (2019). Promosi Kesehatan Kepada Orang Tua Mengenai Perilaku Hidup Bersih dan Sehat untuk Mencegah Hepatitis A pada Anak. Media Karya Kesehatan, 2(1).

Notoatmodjo Soekidjo. Prof, Dr. (2010). Pengantar Pendidikan Kesehatan dan Ilmu Perilaku. Jogjakarta: Andi Offset. 
Udin Rosidin : Penyuluhan tentang Aktifitas Fisik dalam Peningkatan Status Kesehatan

Oktarina, \& Hanafi, Budisuar. (2009). Hubungan antara Karakteristik Responden, Keadaan Wilayah dengan Pengetahuan, Sikap terhadap HIV/AIDS Pada Masyarakat Indonesia. Buletin Penelitian Sistem Kesehatan, 12(4), Badan Penelitian dan Pengembangan Kesehatan, Kemenkes RI.

Promosi Kesehatan. (2017). Booklet "10 Perilaku Hidup Bersih dan Sehat di Rumah Tangga”. Retrieved from https://promkes.net/.../booklet-10-perilaku-hidup-bersihdan-sehat-di-rumah-tangga/

Sarvasti. (2012). Penyakit Jantung Dan Pembuluh Darah Penyebab Utama Kematian Di Duni. RSU Husada Utama Surabaya.

Welis, Wilda \& Sazeli Rifki, Muhamad. (2013). Gizi untuk Aktifitas Fisik dan Kebugaran, ISBN : 978-602-1650-02-8. 